\title{
Decoding the Hermetic Discourse in Salomon Trismosin's Splendor Solis - A Semiotic Study of Three Ways of Reading
}

\author{
'Has it ever occurred to you,' the old lady went on, 'how \\ much we go by what is called, I believe, the context?'
}

Agatha Christie (1977: 73) ${ }^{1}$

\section{Introducing the Hermetic Discourse and Umberto Eco's Diagnosis of Hermetic Semiosis}

Alchemy and the Hermetic Art are terms that denote a most interesting transitional space, circumscribing an opaque region of human cultural history, shared between matter and psyche, between phantasmagoric reveries and practical experiments, between sincere natural theology and conscious fraud. This is an area of human experience that has been notoriously difficult to define and understand, and which has triggered off contradictory interpretations that are, in their own, of semiotic interest.

It has been said that a text - in our case Splendor Solis, and the Hermetic-alchemical texts at large - is a picnic, a Dutch party, in which the author provides the words and the reader, especially a reader with too much or too little erudition, comes up with the meaning of the words. In the dialectics between the intention of the text and the intention of the reader, the reader has triumphed and is dragging the text to whatever use he or she chooses. Umberto Eco has named this triumph of the reader Hermetic semiosis in a series of lectures and has tried to map the mechanisms that characterize the Hermetica and other kindred readings (Eco 1992).

In his first lecture, Interpretation and history, Umberto Eco explores and compares the semiotic workings of second century Hermetism and the

\footnotetext{
${ }^{1}$ The old lady is, of course, Miss Marple.
} 
Hermeticism of the Sixteenth and Seventeenth centuries with the hermeneutics of post-modern literary theory, especially radical reader-oriented studies and what has been called the continuous slippage of meaning. $\mathrm{He}$ also in parts presents the semiotic model that will be used in this study (See ch. VI Psychoanalyzing the Hermetic Discourse). But to contextualize this model we will begin by untangling the afore-mentioned comparison.

Eco begins the lecture by contrasting two diametrically opposite ways of interpreting a text. First he presents, maybe with rhetorical exaggeration, a radical, post-modern, reader-oriented interpretation in which, to carry it to the extremes, the reader has both 'killed' the intentions of the author and of the text, and victoriously uses the text to whatever use he or she fancies. Eco affronts this position, reminding his readers that he in his influential work Opera aperta, he pleaded for an open-ended reading, but, nevertheless, a reading aiming at interpreting a work. Eco is of the opinion that he then studied the dialectics between the rights of the interpreters and the rights of the text, but that in recent times the part played by the interpreters, i.e. by one-sided reader-oriented perspectives, has been too dominating in the hermeneutic field.

The radical opposition to a reader-oriented perspective gone wild is the view that the only valid interpretation is made up of the original intentions of the author. The hunt for this elusive intention is, according to Eco, often complicated and even in many cases of no importance for the interpretation. Eco instead points out that between the intention of the author and the intention of the interpreter it is also possible to take account of the intention of the text (Eco 1992: 23-88).

In this article I will try to give an overview of the general interpretations of alchemy that have been put forward, and apply Umberto Eco's intentional approach to these interpretations, viz. consider them as various sorts of intentions. But foremost, I will use a pseudonymous alchemical tractate from the sixteenth century, Salomon Trismosin's treatise Splendor Solis as an opportunity to picture and evaluate the three main decodings of alchemy that have been attempted; a chemical, a religious-soteriological and a psychological. I also want to explore what I have called the intertextual web in the Hermetic discourse, and see if its mapping can generate usable knowledge about what has, since the Middle Ages, been called alchemy: a term acknowledging the taking up of a science or art which had been cultivated by Muslim and Nestorian scholars, but with its fountainhead in Late Antiquity. In a period when this area of human culture was

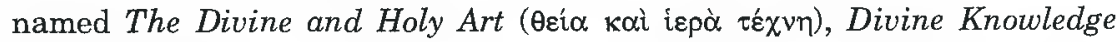

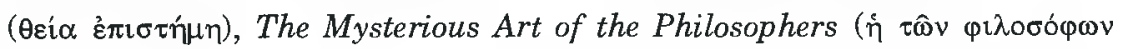




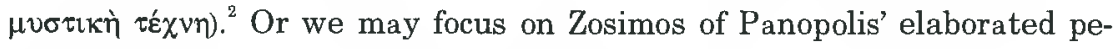
riphrasis of what is going on in the alchemical practise And in this system, single and of many colours, is comprised a research, multiple and varied, subordinated to lunar influences and to the measure of time, which rule the

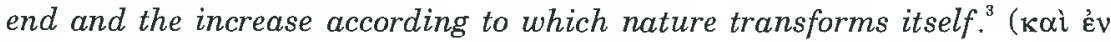

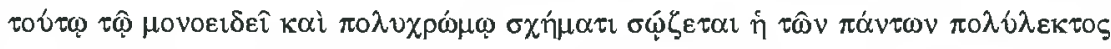

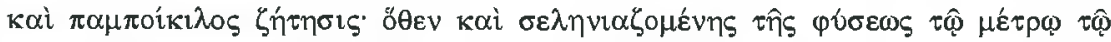

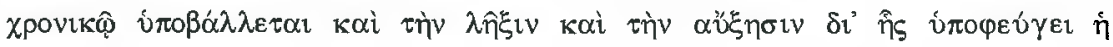

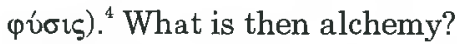

If, for example, we turn to the Concise Oxford Dictionary, we find the current definition 'Medieval forerunner of chemistry, esp. pursuit of transmutation of baser metals into gold or silver; (fig.) transformation like those sought in alchemy'. Already this explanation shows the two main hermeneutical strategies or ways of decoding that characterize much of the secondary literature on alchemy: That it is either seen as misguided protochemistry, which by striving for the then impossible goal of transmuting base metals into silver and gold, ${ }^{5}$ developed laboratory techniques and increased the knowledge of chemical substances and processes. Or it is allegorically used to express, for instance, themes from the Christian theology. Martin Luther writes in his Tischreden (Weimarer Ausgabe vol. 1: 1149):

The science of alchemy [ars alchimica] I like very well, and, indeed, it is truly the natural philosophy of the ancients. I like it not only for the many uses it has in decocting metals and in distilling and sublimating herbs and liquors [in excoquendis metallis, item herbis et liquoribus distillandis ac sublimandis], but also for the sake of the allegory and secret signification, which is exceedingly fine, touching the resurrection of the dead at the Last Day. For, as in a furnace the fire extracts and separates from a substance the other portions, and carries upward the spirit, the life, the sap, the strength, while the unclean matter, the dregs, remain at the bottom, like a dead and worthless carcase [here Luther illustrates further with the preparation of wine, cinnamon, and nutmeg], even so God, at the day of judgement, will separate all things through fire, the righteous from the ungodly. (translation in Warwick Montgomery 1963: 79)

It is maybe permissible to talk about a continuum of possible decodings, going from a practical, experiential to a soteriological, maybe allegorical-

\footnotetext{
${ }^{2}$ For the Greek alchemical terminology and the controversial issue of the Greek and/or Egyptian etymology of the Arab al-kimiya, see Gundel 1950: 240-241 and the references cited.

${ }^{3}$ Translation in Taylor 1937: 89.

4 Zosime de Panopolis 1995: 35 (Mém. auth., x. 1, version a).

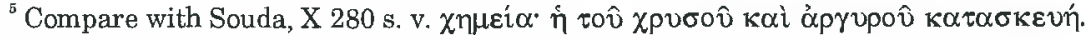


mystical, reading. This has often been presented in terms of exoteric or esoteric alternatives, sometimes, as already indicated, thought to be mutually exclusive. But as a general working definition I will use the following, which Harry J. Sheppard introduced at the symposium concerning Die Alchemie in der Europäischen Kultur und Wissenschaftsgeschichte, Wolfenbüttel 1984, as a marking out of the European alchemy in a universal context:

Alchemy is the art of liberating parts of the Cosmos from temporal existence and achieving perfection which, for metals is gold, and for man longevity, then immortality and, finally redemption. Material perfection was sought through the action of a preparation (Philosophers Stone for metals; Elixir of life for humans), while spiritual ennoblement resulted from some form of inner revelation or other enlightenment (Gnosis, for example, in Hellenistic and western practices). (Sheppard 1986: 16-17)

In Sheppard's definition there is a merging of the two horizons of expectations in that the liberation and perfection of metals and man is set in a correspondence which invites further comparisons, which, in turn, would make up part of a Hermetic world-view, expressing what I in the title of the paper have called The Hermetic Discourse. I am here alluding to Michel Foucault's primary unit of analysis: discourse. Foucault repudiates many of the traditional units of interpretation and analysis, and advocates instead the use of discourse as a system of possibility for knowledge, a summoning up of which rules permit certain statements to be made. Michel Foucault, when discussing what an author is, has tried to capture the meaning of The Hermetic discourse:

Hermes Trismegistus did not exist, nor did Hippocrates - in the sense that Balzac existed - but the fact that several texts have been placed under the same name indicates that there has been established among them a relationship of homogeneity, filiation, authentification of some texts by the use of others, reciprocal explication, or concomitant utilization. The author's name serves to characterize a certain mode of being of discourse: the fact that the discourse has an author's name, that one can say 'this was written by so-andso' or 'so-and-so is its author', shows that this discourse is not ordinary everyday speech that merely comes and goes, not something that is immediately consumable. On the contrary, it is a speech that must be received in a certain mode and that, in a given culture, must receive a certain status. (Foucault 1979: 147)

Foucault has pointed to some extremely interesting topics in this mode of being of discourse: the role of the pseudepigraphical author in relation to the empirical authors of Hermetic tractates; the complicated web of intertextuality by homogeneity, filiation, authentification of some texts by the 
use of others, reciprocal explication, or concomitant utilization. The fact that the discourse is to be received, heard or read, in a specific way, and that this receiving is connected with the social status of the discourse are also important factors for the analysis. Foucault, according to my mind, creates an analytical entity that transcends the limitations of a literary genre, i.e. the nebulous The Hermetic literature a genre-definition which in its own can be useful, but does not show the communicative functions and opportunities of the Hermetic discourse. ${ }^{6}$ I will now use some of Foucault's remarks in introducing Splendor Solis - The Splendour of the Sun.

\section{The Name Salomon Trismosin}

The tractate to be dealt with here is attributed to Salomon Trismosin, ${ }^{7}$ a pseudonymous author, who in his connotations indicate that Splendor Solis belongs to the hermetic discourse, and also, thereby, enforces its authority and social standing. For the name alludes to King Solomon - he who was the wisest of all the sages, and he who built the Temple in Jerusalem with cedar from Lebanon, with gold mined from Ophir and silver from Spain ( 1 Kings) - and to Moses, who is said to have guided the Israelitic People out of Egypt, but who is in Occult literature always connected with Egyptian magic. This Moses is also three times great, a clear reference to the eponymous cultural hero of the literature in question; Hermes Trismegistus. A vital connection is established between a 'suspicious'-looking literature and the canonical, whether in its Jewish or Christian context.

Raphael Patai, in the excellent and much needed work The Jewish Alchemists. A History and Source Book, has systematically collected the attributions of alchemical mastery to biblical figures. In doing so he calls attention to the fact that in Hellenistic Egypt, magical and hermetic texts (if we choose the terminology of Foucault) were already filiated to biblical, canonical texts, and the latter were thereby used to authentificate the more ambivalent genres. Patai maps the complicated intertextual web between biblical texts and the alchemical by, inter alia, pointing out that the thirdcentury papyrus W of Leyden, The Domestic Chemistry of Moses, containing 62 alchemical formulas, paraphrases Exodus 31:1-5; 35:30-35. And, writes Patai, with the obvious intention of pseudepigraphically associating the treatise with the biblical Moses, and thereby endowing it with an aura of

\footnotetext{
${ }^{6}$ See Albinus 1994 for a discussion of 'discourse' as an entity of analysis in the history of religions.

${ }^{7}$ Variant spellings Trissmosin, Trissmosinus. Ferguson 1906: 469-470.
} 
antiquity and authenticity. It is also of interest that one of the most famous alchemical prescriptions for doubling the weight of gold was called Diplosis of Moses (Patai 1994: 18-40). ${ }^{8}$

This Late Antique attribution was taken up in the Middle Ages, when Greek, Syrian and Arab alchemical manuscripts were translated into Latin, and we can find, e. g., in the Margarita preciosa of Petrus Bonus of Ferrara, fl. in the early part of the fourtenth century, references to Moses, David, Solomon, Ovid, Virgil, etc., as associated with alchemy. But the apogee of this biblical genealogy of alchemy can maybe be found in the writings of Paracelsus, who writes about a spiritual substance that was first given to Adam. It was also through its power that Moses built the Tabernacle, Noah the Ark and Solomon the Temple (Patai 1994: 31).

This is strongly in line with a tradition that has been added to a collection of alchemical tractates called Aureum Vellus oder Guldin Schatz..., purporting to be written by Salomon Trismosin, in which the printed version of Splendor Solis is first published. We are told a story of how Salomon Trismosin happened to see an alchemical transmutation effected by a miner, and wanting to do the same started his travels in the year 1473 in search of the Stone. He journeyed widely, but in Venice, he obtained the tincture of transmutation. This miraculous substance did not only prolong life, but also effected rejuvenescence. In sum, it was a medicine so powerful that it could prolong Salomon Trismosin's life to the Last Day. The story also relates that he afterwards, in Constantinople, functioned as teacher to Paracelsus. $^{9}$

This spurious life-story of Salomon Trismosin has, according to my mind, the function of giving the many tractates collected in the Aureum Vellus an aura of historicity, and thereby, also, presents another example of the pseudonymous tradition in the Hermetic discourse. We could perhaps regard the use of pseudonymity or the accrediting of alchemical tractates to well known persons, whether in Late Antiquity, as with the PseudoDemocritean tractates, or in the Middle Ages the works known under the names of Raimond Lull, St Thomas Aquinas, Arnold of Villanova inter alia,

\footnotetext{
${ }^{8}$ The treatise 'The Domestic Chemistry of Moses' is alluded to by Zosimos of Panopolis, a late antique alchemical encyclopaedist which is one of the most important sources of Splendor Solis and which we are going to discuss in detail. Berthelot 1888/2: 182-183; Berthelot 1888/3:180-181, 209, 338. But see now the new edition and commentary by Michèle Mertens in Zosime de Panopolis 1995.)

${ }^{9}$ Aureum Vellus...., Hamburg 1708, Tractatus Primus, ch. 1 'Tractat unnd Wanderschaft dess hochberümpten herren Salomonis Trissmosini, pp. 1-5. See part III for full bibliographical information.
} 
as a way of establishing an intertextuality which attaches Hermetic tractates to well known figures in the general literary discourse, thereby creating a cultural web of value, credibility, and historicity.

But the questions concerning this literature are even further complex, and we should also be prepared to take notice of the following remark of Robert Halleux, when he discusses the motives and uses of the names of cultural luminaries in alchemical pseudoepigraphy:

La réaction instinctive du lecteur est de rejeter en bloc le témoignage des rubriques initiales et finales avec l'arrière-pensée que ces grands esprits ne peuvent avoir donné dans l'alchimie. C'est prêter aux médiévaux un préjugé défavorable à l'alchimie, qui est plutôt le fait de notre époque. On verra plus loin que l'alchimie était, dans la mentalité médiévale, moins 'marginale' qu'on ne pourrait le croire. Mais il n'est pas moins vrai qu'elle ne fut jamais intégrée à l'enseignement universitaire, et que l'attribution à des docteurs en renom peut répondre à un besoin de compensation. (Halleux 1979: 100)

\section{The Manuscripts and Printed Versions of Splendor Solis}

\section{Inventory of the manuscripts}

The social status of the tractate's hermetic discourse, to continue the use of Foucault's observations, is enhanced by the fact that we first meet the text of Splendor Solis in the shape of six beautifully illustrated manuscripts from the sixteenth and early seventeenth centuries. ${ }^{10}$ We find a complete manuscript of vellum, consisting of 67 pages with 22 illuminations in the Staatsbibliothek zu Berlin-Preußischer Kulturbesitz (Ms. germ. qu. 42) earlier in the Kurfürstlich-Brandenburgischen Bibliothek in Berlin. It has been dated to the last third of the sixteenth century by the art-historian

\footnotetext{
${ }^{10}$ The three MSS which are not mentioned in the text of the article are the following: Ms. Ph. Mus. Nr. 1740 (in the new inventory: Hs 146.766) in the Germanischen Nationalmuseum in Nürnberg, which has alterations in both the disposition of the texts and pictures, but with the same elaborate ornamented borders as Ms. germ. qu. 42 . Harley Ms 3469 in the British Museum, inscribed with the date 1582. The Harley MS was used by the Irish poet Yeates when he wrote about the Rosa Alchemica. A manuscript in Switzerland, in private hands, has two more illustrations than the rest: a griffin flying out of a mountain cave, respectively an illumination with Hermes and Chronos (Hartlaub 1991: 126-128). There is also a very incomplete manuscript - damaged during the last war - in Kassel, the Murhardsche Bibliothek und Landesbibliothek Hs Mus. 1954-76. In the Bibliothèque Nationale, Paris, a Ms dated to 1577 , with a note in the preface indicating that it has been owned by Rudolf II, Ms Allemand 113. Lennep 1984: 111.
} 
Gustav Friedrich Hartlaub, and the colour illustrations accompanying this article are photographed from this manuscript.

The original manuscript, dated to 1532 and 1535 by inscriptions in two of the illuminations, is preserved in the Berliner Kupferstichkabinett (codex $78 \mathrm{D} \mathrm{3}$ ). It is rather badly damaged, three pictures are missing, and some of the others have been cut out and then replaced in the wrong places. On stylistic grounds it has been located to Nürnberg and compared with the graphic art that was produced in the city during the early part of the sixteenth century. Especially the famous series of engravings called Planetenkinder, ascribed to H. S. Beham, but more probably to Georg Pencz, have been used. But also, according to Hartlaub, motives from B. Dürer, Aldegrever, H. S. Beham, Burgkmair are modeled in codex 78 D 3. In general: the stylistic setting is reminiscent of Flemish miniatures in the manner of the Hortulus-Master, or the circle around Simon Bening.

In the opinion of Hartlaub the manuscript can be attributed to the Nürnbergian illuminator Nikolaus Glockendon, concerning the astrological charts, and the rest of the folia to an unknown engraver in this context working as an illuminator. Hartlaub does not exclude that older Hermetic literature can be found that functioned as prototypes for some of the illuminations (Hartlaub 1991: 126-128).

Jacques van Lennep, in his grandiose study of 1.015 pictures pertaining to the rich and enigmatic iconographical world of Western alchemy, in general agrees with Hartlaub's attribution, but he makes a small correction: The series called Planetenkinder carries the names of Hans Sebald Beham and Albrecht Glockendon, not Nikolaus. Jaques van Lennep also emphasizes that Splendor Solis was influenced by a missal made for Albert of Brandenbourg, Bishop of Mayence, inscribed with the mark of the workshop of the Flemish Simon Bening, born ca. 1483, deceased ca 1561 (Lennep 1984: 111).

\section{The printed versions}

Splendor Solis was first printed in Rorschach am Bodenzee in 1598 as part of the collection called Aureum Vellus oder Guldin Schatz und KunstKammer, which also purports to be written by Salomon Trismosin. Another edition was printed in Basel in 1604, but I have been using the Hamburg edition of 1708 , and three engravings from it accompany my article (see ill. 


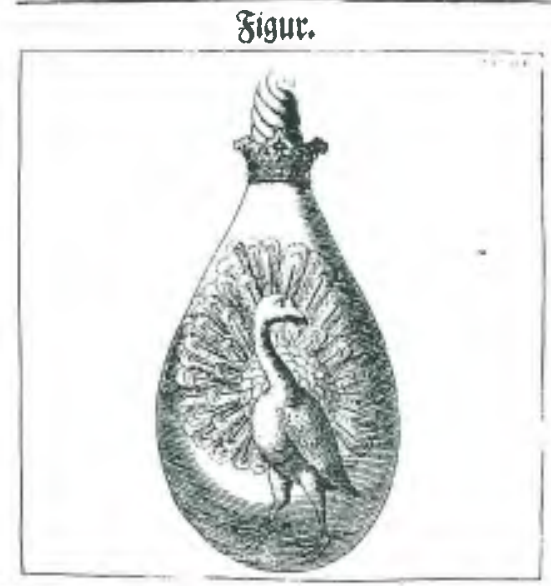

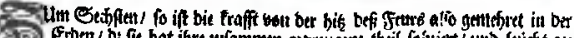

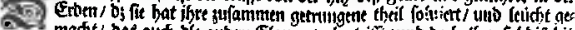

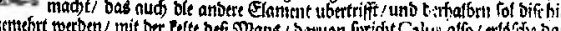
政 Sing binges.

3 3ut

IIl. 1. A peacock in an alchemical vessel, a symbol often indicating the whole opus alchemicum. From the printed edition of Splendor Solis in Aureum vellus, Hamburg 1708, p. 193. Compare with illustr. 5.

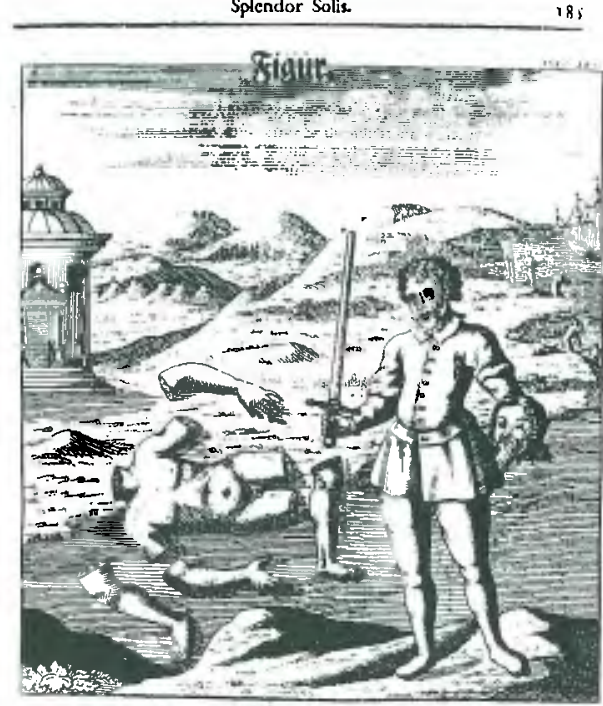

Aa

Ill. 2. The transformation or dismemberment of the body of a man serving as a metaphor for the transmutation of a metal body. From Splendor Solis in Aureum vellus, Hamburg 1708, p. 185. Compare with illustr. 6 and the analysis in the article.

Splendor Solis.

13.

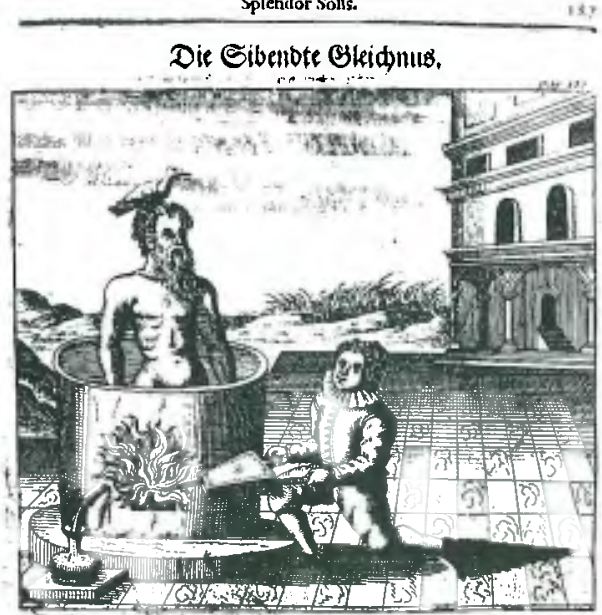

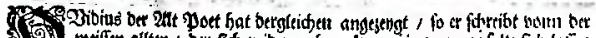

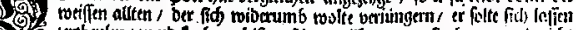

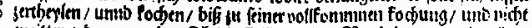

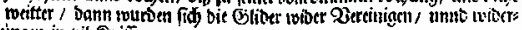
umb otriungen in bil Sirificte.

$\mathfrak{A}$ a

Seriad

Ill. 3. The rejuvenation of an old man. From Splendor Solis in Aureum vellus, Hamburg 1708, p. 187. See also illustr. 7.

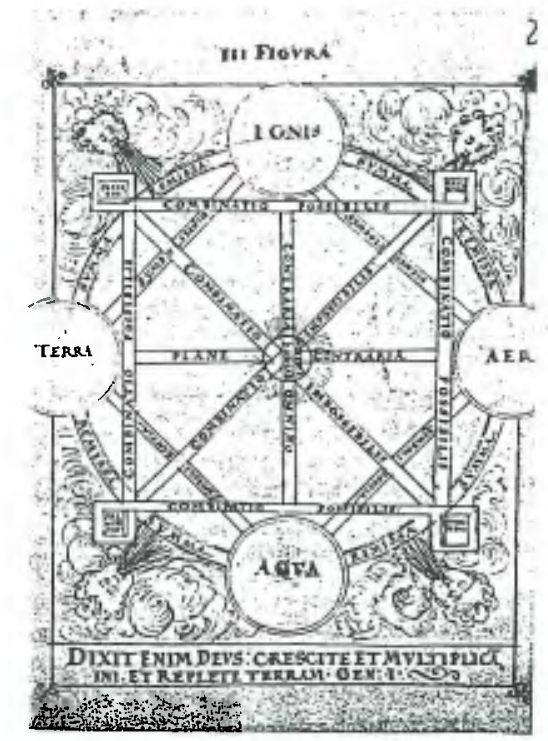

Ill. 4. The elements as illustrated in Cornelius Petraeus, Sylva Philosophorum, 17th century, Bibliotheek der Rijksuniversiteit, Leiden, Cod. Voss. chem. q. 61. 


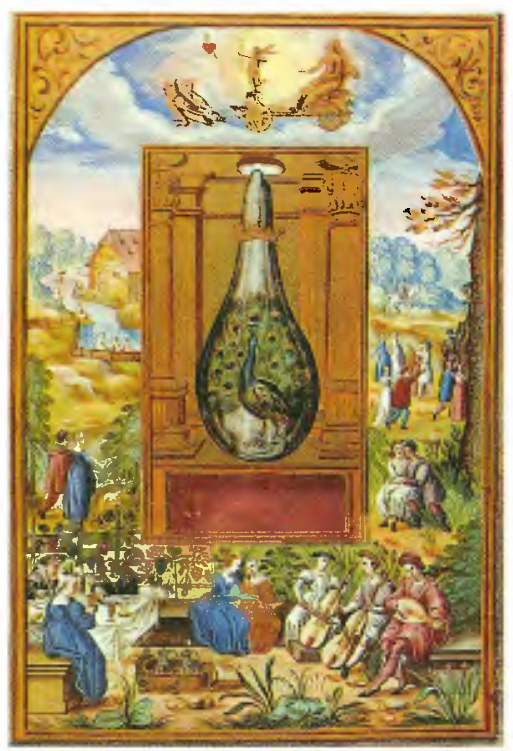

III. 5. A crowned alchemical vessel with a peacock showing its manycolored wings, an allusion to the color-stages of the opus alchemicum. From Splendor Solis in Staatsbibliothek zu Berlin-

Preussischer Kulturbesitz, Ms. germ. qu. 42 fol. 46. See illustr. 1.

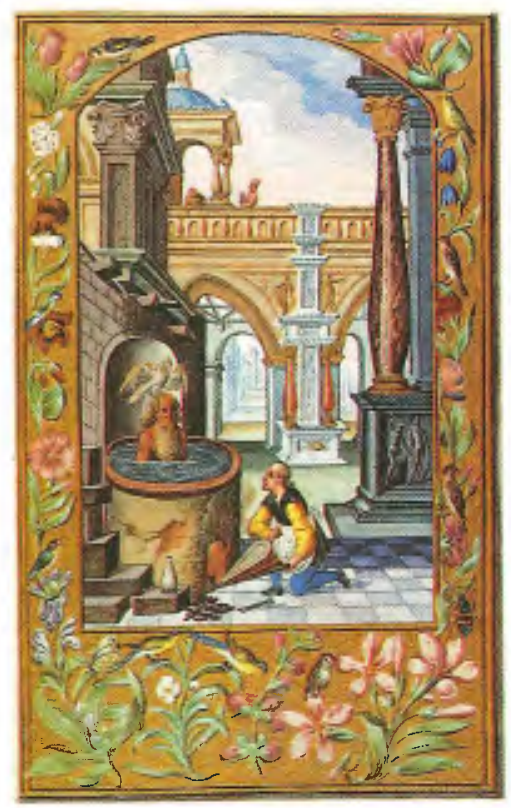

Ill. 7. The rejuvenation of an old bearded man. From Splendor Solis in Staatsbibliothek zu BerlinPreussischer Kulturbesitz, Ms. germ. qu. 42 fol. 36 . See illustr. 3.

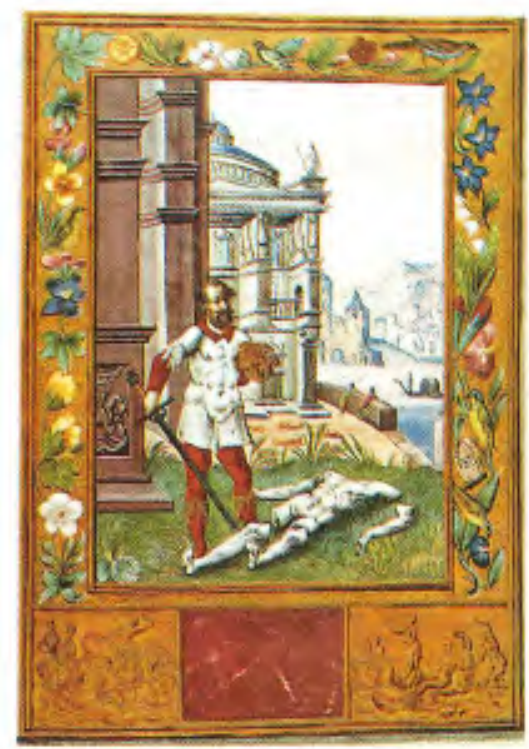

Ill. 6. The transformation or dismemberment of the body of a man serving as a metaphor for the transmutation of a metal body.

From Splendor Solis in

Staatsbibliothek zu Berlin-

Preussischer Kulturbesitz, Ms. germ. qu. 42 fol. 34. See illustr. 2.

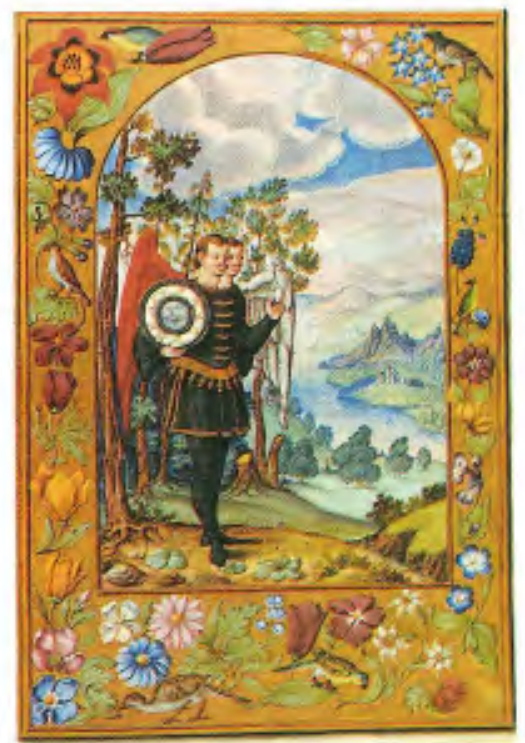

Ill. 8. Lapis philosophorum in the form of a hermaphrodite, a rebis which holds up an egg and a mirror, symbols of completeness and perfection. From Splendor Solis in Staatsbibliothek zu BerlinPreussischer Kulturbesitz, Ms. germ. qu. 42 fol. 32 . 
1-3). ${ }^{11}$ The full title of this edition is given below. Notice how the title of the collection, like a modern trailer in the media, introduces and entices the consumer to buy the product:

Aureum Vellus oder Guldin Schatz und Kunst-Kammer Darinnen der aller fürnemisten/fürtreffenlichsten/ ausserlesenesten/herrlichisten und bewehrtesten Auctorum Schrifften und Bücher/auss dem gar uralten Schatz der uberblibnen/verborgnen/hinderhaltenen Reliquien und Monumenten der Aegyptiorum, Arabum, Chaldaeorum \& Assyriorum Königen und Weisen. Von Dem Edlen, Hocherleuchten/fürtreffenlichen/bewehrten Philosopho Salomone Trissmosino (so dess grossen Philosophi und Medici Theophrasti Paracelsi Praeceptor gewesen) in sonderbare unterschiedliche Tractätlein disponiert/ und in das Teutsch gebracht. Sampt anderen Philosophischen alter unnd newer Scribenten sonderbaren Tractätlein/alles zuvor niemalen weder erhört noch gesehen/wie der Catalogus gleich nach der Vorrede zuverstehen gibt. Durch einen der Kunst liebhabern mit grossen Kosten/Mühe/Arbeyt und Gefahr die Originalia und Handschrifften zusammen gebracht/und auffs fremlichest und fleissigst an Tag geben.

The title Aureum Vellus - the Golden Fleece in the story of Jason and the Argonauts - is here here put to a use that we can read about already in the Byzantine encyclopaedia Suidas (ca A. D. 1000), which relates that even though the Golden Fleece is associated with Jason, this is not the full story; in fact, according to Suidas, it was a book, written upon sheep-skin, teaching how gold could be made. For in those times it was natural to call the skin or parchment golden due to this process. ${ }^{12}$

Splendor Solis is printed in the third part of Aureum Vellus under the title 1. Splendor Solis mit schönen Figuren, pp. 166-213, and is followed by 2. Spiegel der Alchymea herrn Ulricic Poyselii. ${ }^{13}$

Adam McLean, a keen publisher and traditional esoteric commentator, gives us some more information: An elaborated French translation, by the acronym L. I., was published in Paris in 1612 as La Toyson d'or, ou La Fleur des thesors. This was later used by William Backhouse, alchemical teacher to Elias Ashmole, in the translation Salomon Trismosin, The Golden Fleece or the Flower of Treasures, on the Philosopher's Stone (British Library MSS Sloane 2503; 3613). Elias Ashmole copied

\footnotetext{
${ }^{11}$ Vormahls gedruckt zu Rorschach am Bodensee/ Anno M. D. XCVIII. und zu Basel 1604 in fünff verschiedenen Tractaten; itzo aufs neue auffgelegt und in ein Volumen gebracht. Hamburg/ bey Christian Liebezeit/ in der St. Joh. Kirch/1708.

${ }^{12}$ s. v. $\Delta$ épos. Suidas, quoting Photius of the ninth century, who in turn says that he obtained the information from John of Antioch in the seventh century.

${ }^{13}$ For a complete catalogue of the volume see Kopp 1886: 242-244, who also annotates other works which use the story reported in Suidas.
} 
Backhouse's translation, and also translated some other tractates attributed to Salomon Trismosin (Trismosin 1981: 1-4). ${ }^{14}$

A certain Julius Kohn, Austrian refugee and adept to Rev. W. A. Ayton, member of the Hermetic Order of the Golden Dawn, prepared an English translation of the Splendor Solis manuscript in the British Museum, and published Splendor Solis under the acronym J. K., in the publishing-house Kegan Paul, London 1920. Kohn was himself following the Western occult tradition, and waged war against Madame Blawatsky's Eastern esoterism.

It can also be of interest to note, according to McLean, that S. L. MacGregor Mathers, who combined so many occult traditions in the Hermetic Order of the Golden Dawn, studied Splendor Solis and is said to have published a translation by F. L. Gardner in 1907 (Trismosin 1981: 4).

\section{Splendor Solis and the Hermetic Discourse}

Splendor Solis is divided into seven treatises which more or less stand independent of each other. They all discuss the making of the Philosopher's Stone and the beneficient uses to which it can be put. We could perhaps regard the seven treatises as variations on this theme. But the work has a preface - Vorrede - that binds the work together and gives some of the philosophical background:

Alphidius, one of the ancient Sages, says: 'If someone is unable to accomplish something in the Art of the Philospher's Stone, it were better for him not to throw himself into it at all than to attempt it partially.' Rhases gives the same advice in the book 'Lumen Luminum', and it should be carefully heeded: 'I hereby exhort you most strongly that no-one should dare to attempt the ignorant mingling of the elements.' And Rosinus agrees with this, saying: 'All who venture upon this art, lacking intelligence and discernment of the things which the philosophers have written in their books, will find them incomprehensible.' For the philosophers have grounded this art in a natural beginning, but a concealed operation.

It is evident, however, that all bodily things derive their origin from the earth, and similarly also their being, according to the laws of time, through the influence of the stars or planets - Sun, Moon and the rest - together with the four qualities of the elements which agitate them ceaselessly. By this means each and every growing form and fruitful thing is brought forth with the type and form proper to its own substance, just as it was constituted and ordained by God at the beginning.

${ }^{14}$ Bodleian Library MS Ashmole 7597 (Black's Cat. 1395); MS Ashmole (Black's Cat. 1408) in Trismosin 1981: 5-6). 
All metals, accordingly, also derive their origin from the earth, having flowed together into separate and specific material from the four elements, with the implantation of the metallic forces; and the influence of the planets aids their assemblage. Aristotle, the Natural Master, described it as such in the fourth book of his 'Meteors', where he tells how quicksilver is a material common to all metals; but it should be known that the first thing in Nature is the material gathered together out of the four elements through Nature's own knowledge and capacity. The philosophers call this material Mercury or Quicksilver. It is not a common mercury: through the operation of Nature it achieves a perfect form, that of gold, silver, or of both metals. There is no need to tell of it here: the natural teachers describe it very clearly and adequately in their books. On this the whole art of the Stone of the Wise is based and grounded, for it has its inception in Nature, and from it follows a natural conclusion in the proper form, through proper natural means. (Godwin's translation in Trismosin 1981: 9)

It is, of course, impossible in this short article to comment upon all the information and particularities of the passage, but I will point to some general features. In the first paragraph some of the old philosophers have expressed concern over the personal qualifications of a would-be adept. Notice also that the operation is grounded in nature, but of a secret kind.

The rest of the passage deals with the fact that all materia is thought to emanate from the earth, and is 'agitated' by the four elements, hereby giving reference to two of Aristotle's key thoughts: the theory of the elements, and the thought that all Nature is teleological, aiming at perfection within each and every different class and family of things. Because, according to Aristotle, the ultimate entity in the material world is $v \lambda_{\eta}-$ materia prima - which only has a potential existence before it is provided with a

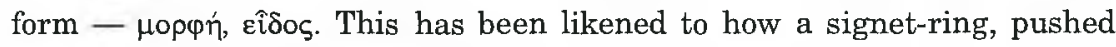
into heated wax, formes an image. The form is made up of the four elements in their characterizing qualities, and the type of the particular form is determined by the proportions of the elements. Each and every single thing is then a conjunction of form with matter.

This thinking is illustrated in Cornelius Petraeus' Sylva Philosophorum (see illustr. 4). Ignis, fire, is characterized by dryness and heat, and these can, as shown, be combined. Earth, in its turn, is dominated by dryness and coldness. The alchemist thought that he could transmute earth to fire by changing the coldness into warmth, and keeping the dryness. Transmutation was thought possible, and a substance could be made by mixing the elements so that they would have the same proportions as the elements in the substance that was desirable.

Gold was thought to be composed of the four elements in perfect proportion, and as Nature, according to Aristotle, is striving after perfection, the 
other metals will, in their due time, be perfected and be transmuted to gold. The Alchemist may speed up this teleology of metals by his processes. It is stated in Splendor Solis that the Philosopher's Stone will effect this shortened ripening:

Thus this Art possesses a wondrous thing, its beginnings rooted in Nature, to which Nature could never give birth by itself: for Nature by itself could never produce the thing through which the metals, imperfectly made by Nature, can be born. Through the secrets of the art they can be made rapidly and manifested complete, born from temporal matter through Nature. Nature serves Art, and then again Art serves Nature with a timely instrument and a certain operation. (Godwin's translation in Trismosin 1981: 10)

The perfection is not only limited to the perfections of the metals, but is sometimes thought to contain both the microcosmos of Mankind and the macrocosmos at large. One of the most beautiful illuminations in Splendor Solis (see illustr. 5; fol. 46 in the manuscript), shows what is perhaps to be seen as an alchemical Paradisus Terrestris. In the center of the miniature is a crowned vessel of glass alluding to the term Ars Regia - The Royal Art used as a code-word for alchemy - and in the Hermetic vessel a peacock with its wings spread out - cauda pavonis - with reference to the colorstages of the alchemical work. The vessel is set in the niche of an architectural structure, framed by two composite columns coupled to pilasters, but with an aperture in the structure which gives free access to the happenings in Heaven, so that the processes in the vessel are astrologically influenced by Venus. She is seated in a wagon drawn by two turtle-doves with wheelspokes indicating that Venus is in Aries and Libra. But she is also influencing the making of harmonious music, drinking, bathing and love-making that are going on in the pastoral scenery - a reflection of the passions and conjunctions of metals that are going to take place within the Hermetic vessel. This is an illumination which in all its details points to the fundamental alchemical theme of coniunctio oppositorum - the uniting of opposites whether man or metals. It is a theme that in its emphasis on the sympathetic forces in the world also alludes to the common alchemical monism - that everything fundamentally is One as expressed, e. g., in the influential Tabula Smaragdina. ${ }^{15}$

The perfection of base metals into gold was usually thought to take place in conformity with the change of colors in the vessel in a series of trans-

\footnotetext{
${ }^{15}$ True it is, without falsehood, certain and most true. That which is above is like to that which is below, and that which is below is like to that which is above, to accomplish the miracles of one thing. And as all things were by the contemplation of one, so all things arose from this one thing by a single act of adaption Holmyard 1957: 97.
} 
formations from blackening (nigredo, $\mu \varepsilon \lambda \alpha \dot{\alpha} v \omega \sigma \iota \varsigma)$, whitening (albedo, $\lambda \varepsilon v ́ \kappa-$ $\omega \sigma \iota \varsigma)$ to yellowing (citrinitas $\xi^{\alpha} \alpha \theta \omega \sigma \iota \varsigma$ ) and to violet-coloring (rubedo, í $\omega \sigma \mathrm{s})$.

The different alchemical processes are of course legio. We can perhaps differentiate between aurifactive operations, i.e. chemically and technichally realizable processes aiming at tinting a metal, overlaying it with a silver or golden patina in imitation of the look of real genuine silver or gold. Or the recipes were used to make false gems. Both of these types of procedures can be found in the famous Stockholm and Leyden Greek alchemical papyri, which were purchased in Thebes in Egypt by the SwedishNorwegian vice-consul Johann d'Anastasi (later general consul) in Alexandria (Halleux 1981: 5-6). Other techniques are aurifactive, that is that their aim was to produce an alchemical gold with at least the qualities of ordinary gold. ${ }^{16}$

But what of Splendor Solis? Do the texts point to any of these categories of alchemy? Julius Kohn, in his translation of the manuscript in the British Museum, gives the following interpretation:

As a Guide to Physical and Spiritual adeptship, Splendor Solis stands both for Gold Splendour and Soul Splendour, and intends to convey the Secret of Physical Alchemy by the text, and of Spiritual Alchemy by the Allegorical pictures, (Kohn 1920: 8)

We are here focusing on a tendency of alchemical texts that they either can be viewed as an allegorization of chemical-technical procedures, perhaps encoding them for the keeping of trade-secrets, and/or the texts are put to a religious use, just as Luther sees the Art both as practical and, in a hidden way pointing to the Christian discourse. ${ }^{17}$ This is in line with how the Byzantine alchemists Stephanos, Archelaos, Heliodoros, beginning in the sixth century, through the alchemical imagery expounded the Orthodox dogmatics concerning the Fall and Redemption of Mankind.

\footnotetext{
${ }^{16}$ The terms are used in accordance with Needham 1974: 10.

${ }^{17}$ See Averil Cameron's Christianity and the Rhetoric of Empire in which she rightly emphasizes 'We are also in the midst of an intense interest in discourse, the expression of ideas. Christianity was not just ritual. It placed an extraordinary premium on verbal formulation; speech constituted one of its basic metaphors, and it framed itself around written texts. Quite soon this very emphasis on the verbal formulation of the faith led to a self-imposed restriction - an attempt, eventually on the whole successful, to impose an authority of discourse. And eventually - though only after much struggle and with many variations - this approved discourse came to be the dominant one in the state'. Cameron 1991: 19.
} 


\section{The Intertextuality of the Hermetic Discourse}

We will now on the basis of some interesting parables in the third treatise of Splendor Solis take a further step back in history to the Egypt of Late Antiquity and to some of the most important Greek alchemical texts, and thereby show in which historical context these double-encodings were first situated. Salomon Trismosin writes in Splendor Solis:

Rosinus says that he was shown a vision of a man who was dead, and whose body was completely white like salt. His limbs were cut off, and his head was of fine gold but sundered from the body. By him stood a monstruous man, ghastly of aspect and black, a two-edged sword in his right hand, stained with blood. In his left hand he held a piece of paper on which was written: 'I have slain you that you may possess abundant life; but your head I will conceal, that the world shall not see you. I will lay waste your body upon the earth, and bury it, that it may become putrid and multiply itself, and bring forth fruits unnumbered'. (Godwin's translation in Trismosin 1981: 28)

The accompanying illumination (see illustr. 6; fol. 34) is at some points at variance with the text, but definitively represents the scene, here set on the outskirts of a town. The ending of the narrative passage is of course replete with Christian connotations, but the main part of the text clearly shows a dependence on Zosimos of Panopolis tractate Of Virtue. Zosimos is one of the most important compilators of the Greek alchemy, and is usually thought to have been working in Alexandria in the latter part of the fourth century. ${ }^{18}$ The name Rosinus is one of the Arab transliterations of Zosimos. ${ }^{19}$ The text of the tractate of Virtue - MEPI APETH $\Sigma$ is found in Michèle Mertens new edition in Les Alchimistes Grecs, tome IV $1^{\text {ra }}$ partie, Zosime de Panopolis Mémoire authentiques. ${ }^{20}$ and I will be citing relevant parts of the Greek text in the footnotes to the following translation made by F. Sherwood Taylor, with some smaller adjustments:

Saying these things I went to sleep, and I saw a sacrificing priest standing before me at the top of an altar in the form of a bowl. ${ }^{21}$ This altar had 15 steps

\footnotetext{
${ }^{18}$ Concerning Zosimos in general, see Fowden 1993: 120-125 and Michèle Mertens' very thorough and important historical introduction. Zosime de Panopolis 1995: XCXII.

${ }^{19}$ See Fuat Sezgin's indispensable Geschichte des Arabischen Schrifttums for an appraisal of Zosimos of Panopolis influence in the Muslim learned world. Sezgin 1971: 7377.

${ }^{20}$ Berthelot and Ruelle's Collection des Anciens Alchimistes Grecs, vol III. I. 1-8 (Berthelot 1888/3: 107-109) is concerning Zosimos of Panopolis superceded by Mertens' new edition.

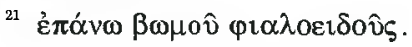


leading up to it. Then the priest stood up and I heard a voice from above saying to me, 'I have accomplished the descent of the 15 steps of darkness and the ascent of the steps of light and it is he who sacrifices, that renews me, casting away the coarseness of the body; and being consecrated priest by necessity, I become a spirit'. And having heard the voice of him who stood on the bowl-shaped altar, I questioned him, wishing to find out who he was. He answered me in a weak voice, saying ' $I$ am Ion, the priest of the sanctuary, ${ }^{22}$ and I have survived intolerable violence. For one came headlong in the morning, dismembering me with a sword, and tearing me asunder according to the rigour of harmony. And flaying my head with the sword which he held fast, he mingled my bones with my flesh and burned them in the fire of the treatment, until I learnt by the transformation of the body to become a spirit'. And while yet he spoke these words to me, and I forced him to speak of it, his eyes became as blood and he vomited up all his flesh, and I saw him as a mutilated little figure of a man, ${ }^{23}$ tearing himself with his own teeth and falling away.

And being afraid I awoke and thought 'Is this not the situation of the waters?' I believed that I had understood it well, and I fell asleep anew. And I saw the same altar in the form of a bowl and at the top the water bubbling, and many people in it endlessly. And there was no one outside the altar whom I could ask. I then went up towards the altar to view the spectacle, and I saw a little man, a barber, whitened by years, who said to me 'What are you looking at?' I answered him that I marvelled at the boiling of the water and the men, burnt yet living. And he answered me saying 'This spectacle you are looking at is an entrance, a way out and a transition.' I inquired of him again 'Which transition?' ${ }^{24}$ And he answered me saying 'It is the place of the exercise called preserving (embalming) ${ }^{25}$ For those men who wish to obtain virtue come hither and become spirits, fleeing from the body'.

How should this passage be decoded? I would presume that it is most profitably read as a complex discourse linking a chemical interpretation to a religious - soteriological - explication. Accordingly, I propose that the text has been consciously encoded in such a way that the reader cannot finally decide to read it without thinking on both perspectives. I also find

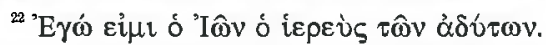

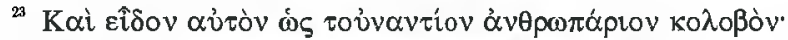

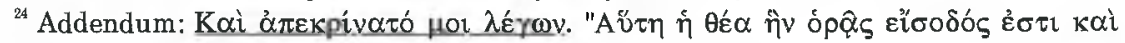

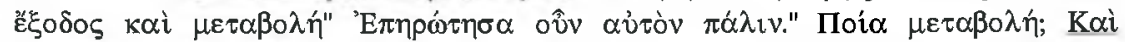

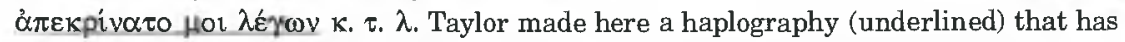
not been noted in the later secondary literature. Lindsay 1970: 344 and some later authors have not checked with the the Greek text, but use Sherwood Taylor's translation indiscriminately.

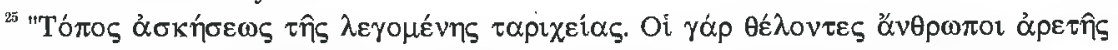

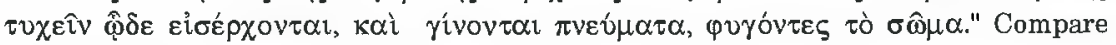
Olympiodoros Concerning the Sacred Art 49 in Berthelot 1888/3: 99).
} 
these interpretations present in the text as textual intentions that are to be read in reference to each other. The explicit textual strategy consists in the reading - the decoding - oscillating between these interpretations. But for the clarity of arguments, I will first introduce the chemical reading, and then the soteriological.

The chemical interpretation has been forwarded by historians of chemistry (see also Hopkins 1938: 326-343), and I will here follow Sherwood Taylor's reconstruction of the function of the kerotakis - apparatus, the Late Antique counterpart to the modern reflux-extractor. This interpretation is based upon the hypothesis that the process going on in Zosimos' bowled-shaped altar is a veiled rendering of either the creation of an alloy which in itself has a golden tint, or the tinting of an alloy - giving it a thin golden surface-film - in the afore-mentioned apparatus. The lexical

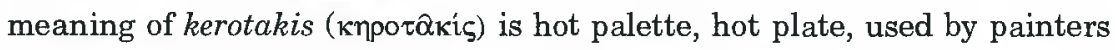
for keeping wax paints hot. ${ }^{26}$ Pliny the Elder relates in Naturalis Historia 35.31 that it was the custom to paint with black, white, yellow, and red pigments - compare with the color-stages - which were mixed in hot wax to make possible encaustic paintings, e. g., the late Ptolemaic and Roman mummy portraits from Fayum.

Accordingly, a plate, kept hot with a vessel filled with burning charcoal, functioned as a palette. The alchemists probably thought that they could make the alloy softened, and so impregnate it with colors, as also textiles were colored through 'baptisms' in reagents.

The invention of the Kerotakis-apparatus is by Zosimos and other Greek alchemists accredited to Mary the Jewess, whom Zosimos often cites and gives the name the divine Maria. He also refers to a treatise On Furnaces and Apparatuses in which Mary the Jewess has collected the sayings of the ancients concerning these matters. What is of special interest in this context is that it was Zosimos' sister - whether biological or perhaps spiritually meant - Theosebeia, who asked her brother for information on the subject. Women of different religious belongings seem to play an active part in early Greek alchemy; one can compare it with the activity of women in the ownership of agricultural properties, and in the textile industry (Bagnall 1993: 92-99). Mary has much to say about, for instance, the water-bath (balneum Mariae), and the processes in the kerotakis (Lippmann

\footnotetext{
${ }^{26}$ sub voce in Liddell and Scott, A Greek-English Lexicon, Oxford reprint. 1948.
} 
1919: 46-50; Patai 1993: 60-91), but I must, due to the limited space, refer to a forthcoming article. ${ }^{27}$

But how did this aurifictive process, based upon the tinting of alloys, take place in the kerotakis-apparatus? Sherwood Taylor proposes that an alloy containing a high percentage of copper or an alloy of four base metals was placed on the kerotakis, (see illustr. 9; from Berthelot 1888/1: 143, i.e. Marcianus 299 fol. 196v.), in the upper part of the apparatus. Mercury set in the lower part was then heated by a charcoal-fire, boiled and condensed on the alloy and on the upper part of the apparatus. The alloy disintegrated and finally dissolved. Impurities, oxides, etc., were collected on the kerotakis and on the sieve below. Under this was a pure copper amalgam collected in the part of the apparatus where it is pointed out that it is a vessel of earthen-ware

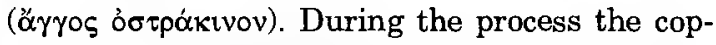
per-alloy desintegrates, as just stated, which could correspond to the blackening stage (nigredo, $\left.\mu \varepsilon \lambda \alpha \alpha^{\prime} \omega \sigma \iota \varsigma\right)$. The amalgam which is white, because it contains much mercury, could

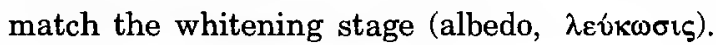
Through continued heating the percentage of mercury can be lowered so that an amalgam containing approximately $13 \%$ mercury is achieved. This has a yellow, goldened surface, which then would stand for the yellowing stage

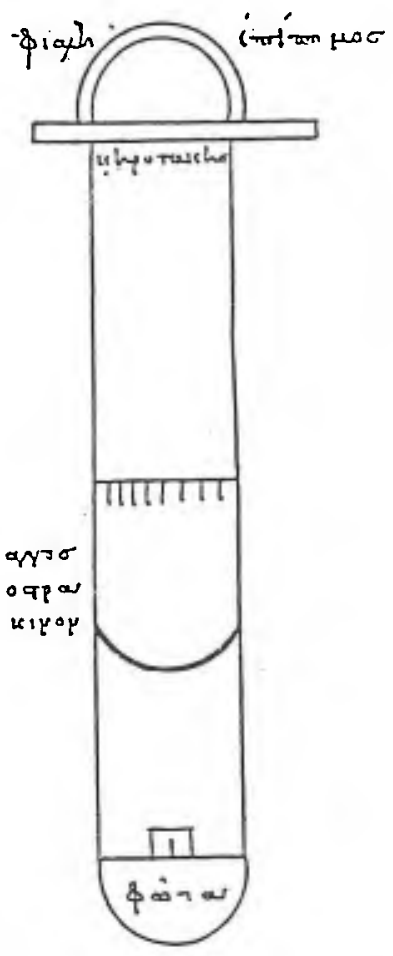

Ill. 9. The kerotakisapparatus. From Marcianus 299 fol. 196v. in Berthelot 1888/1 p. 143. (citrinitas $\xi \alpha \dot{v} \theta \omega \sigma \iota \varsigma)$. Even nowadays this specific alloy is sometimes used for artificial gold (Taylor 1930: $130-135)^{28}$

\footnotetext{
${ }^{27}$ Hermetic Monism and Sexual Imagery among Female Alchemists in Late Antique Alexandria, which I hope to publish during 1997.

${ }^{28}$ If sulphur or arsenic sulphur is used, it would also be placed in the lower part of the apparatus. The metals on the kerotakis would be converted to sulphides which might dissolve in the melted condensed sulphur and then drop back to the lower part of the apparatus. This mixture was called black lead ( $\mu \delta \lambda \nu \beta \delta \circ \varsigma \mu_{\varepsilon} \lambda \alpha \varsigma$ ) and was found in $H a$ des, the lower part of the apparatus. It could thereafter be treated in various ways. Taylor 1930: 135-137.
} 
Then it remains to explain the last phase, the violet-coloring. Sherwood Taylor points out that no explanation of the process can be given, even though A. J. Hopkins has proposed that it was a violet-coloring, tinting of metals, like the Japanese shaku-do (Taylor 1930: 133 note 22). But this violet-coloring hypothesis has recently been confirmed by Paul T. Craddock and Alessandra R. Giumlia-Mair, specialists in ancient technologies, which emphasize that more or less the same process was used to produce either shaku-do, or the among classical authors famous Corinthium aes. They also find that this technique was in practise in Ancient Egypt and taken over in the Greek alchemy, under the name iosis (i $\omega \sigma \iota \varsigma$, later called rubedo). In this process an alloy containing much copper and small amounts of silver and gold was dipped into solutions of acetic and oxalic acids to accomplish a shining black-violet surface (Craddock and GiumliaMair 1993).

What, then, of the religious- soteriological reading? Some of the historians of science have studied the Greek alchemy in a very biased way, explicitly eliminating what they regard as the superstitions and religious ecstasies of Zosimus (Hopkins 1938: 327), others emphasize that the religious atmosphere is present in almost all alchemical texts, and that the religious element in Greek alchemical works links them to Egypt rather than to Greece (Taylor 1930: 110).

Already Reinesius, in Fabricius Bibliotheca Graeca XII. 733, certifies that Zosimos recounts old Egyptian and Greek fables he found in Hermes Trismegistos' Pimander, that is Corpus Hermeticum (hereafter abbreviated C. H.), because from the Renaissance onwards the collection was named after the first treatise. Richard Reitzenstein, Walter Scott, pater Festugière, and recently Garth Fowden (1993: 122-123) also point out the connection between the Zosimian corpus and the revelatory dialogues in C. H., especially The Mixing-bowl or Monad (C. H. 4). We can, namely, read that Zosimos in an exhortation to his sister Theosebeia ${ }^{29}$ urges her to abandon passion, lust and anger, and when she has realized that perfection has been attained and the natural tinctures found, to spit on matter, hastening towards Poimenandres and being 'baptized' in the mixing-bowl, hastily ascend to her own kind (Festugière 1950: 367-368).

The Mixing-bowl or Monad (C. H. 4) purports to be written by Hermes to Tat, treating the ascension of the soul to God, the One and the Good, and teaching ascetic avoidance of bodily sensations:

\footnotetext{
${ }^{29}$ Mertens offers strong arguments for it being a compilation of material from Zosimos, but collected by an épitomateur. Zosime de Panopolis 1995: LX.
} 
He (God) filled a large krater with this (the Nous), sent it down and added a messenger, and enjoined him to announce this to the hearts of men: ${ }^{30}$ you who are able, baptize yourself in this krater, you who trust that you can ascend to Him who has sent down this krater, you who know to what you are born. All who understood the message and were baptized with the Nous, took part of the Wisdom and became complete men, having received the Nous. (Nilsson 1958: 57)

On this basis the afore-mentioned passage from Zosimos' Of Virtue with its violent dream-scenes could be read as showing a common Late Antique religious theme; the ascetic escape from the human body and its sensations through exercises which dry out the bodily fluids - 'It is the place of the exercise called preserving (embalming).$^{31}$ For those men who wish to obtain virtue come hither and become spirits, fleeing from the body'.

Consequently, my thesis is that Zosimos' treatise Of Virtue is to be read as a coherent didactic discourse, which is given in the form of divinatory dreams, in which the reader identifies with the interlocutor, who, both in the dreams and in an awakened state, explicates the soteriological virtues of ascetism for man and metal.

How does this decoding then correspond with the parable of Splendor Solis which related the story of Rosinus-Zosimos that we have written so much about?

I would venture to suggest that we are confronted with a phenomenon already noticed by Helmut Birkhan in his description of the alchemy of the didactic poem of Gratheus, filius philosophi (Cod. Vind. 2372):

Die allegorisch-spirituelle Alchemie, der das Werk des Gratheus zugehört, war und bleib eine Geheimwissenschaft, deren 'Axiome' und Denkschemata in die Spätantike zurückreichten, jedenfalls seit Jahrhunderten feststanden: geschlechtliche Vereinigung, Zeugung, Geburt, Tod unter Qual und Leiden,

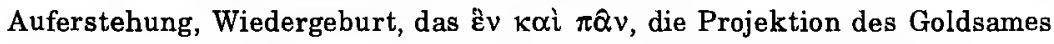
in die wie Teig $(\mu \alpha \dot{\zeta} \zeta \alpha)$ gedachte Materie, in der er transmutierend fermentiert usw. Diese Gedanken ziehen sich durch die Jahrhunderte, in neuen Kombinationen zwar, und mit neu benannten Stoffen, sind aber z. B. bei John Dee im 16. Jh., ebenso nachweisbar wie bei Zosimos, Morienus und anderen alten Meistern. (Birkhan 1992: 53-54)

\footnotetext{
${ }^{30}$ Compare with The Shepherd of Hermas. Mandates 6.2.1-4 when Hermas relates how the angel of justice comes into your heart speaking about justice, purity, holiness, in contrast to the angel of wickedness who is of a violent temper, bitter, and silly. I would suggest that the heart is imbued by Nous in the Hermetic text as a metaphor expressing something like the inspiration and indwelling of the angel of justice in the aforementioned text.

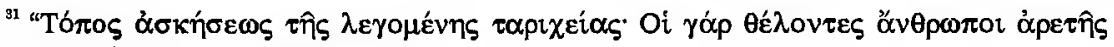

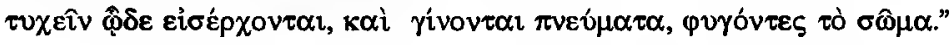


Birkhan points to a limited numbers of topoi that are put to use again and again, thereby creating what could be called the intertextual web of Hermetic - alchemical literature. The Hermetic discourse is made up of these intertextual associations that often reflect each other, and can be seen as giving the reader a continuum of possible decodings, going from a practical, experiential to a soteriological, maybe allegorical-mystical, reading.

This is further confirmed if we go back to Splendor Solis and take a look at the text and the illumination of the seventh parable that follows Rosinus' statements:

Ovid, the ancient poet, indicated something similar when he wrote of the wise old man who wanted to be made young again. He is said to have had himself cut up and boiled until he was perfectly cooked, and no more, then his members would unite again and be rejuvenated with great strength. (Godwin's translation in Trismosin 1981: 30)

This can be read, in compliance with the sixth parable, both as veiled allusions to practical alchemical processes, the transformation of the body of a man serving as a metaphor for transmutation of a metal body, and as a a soteriological transformation which gives health to the human body.

In the illumination (Illustr. 7; fol. 36) an old bearded man awaits spiritual and corporal rejuvenescence in a vessel filled with water, and an assistant is puffing up the fire so that the water can begin to boil. A dove has placed herself on the head of the man, perhaps an allusion to the Holy Spirit present at baptism. A contemporary reader of Splendor Solis could perhaps recollect those enigmatic words made by John the Baptist, as an answer to the people's question if he were the Christ; I baptize you with water; but he who is mightier than I is coming, the thong of whose sandals I am not worthy to untie; he will baptize you with the Holy Spirit and with fire. (St. Luke 3: 15-16a) ${ }^{32}$

Notice also the flasks, in the foreground of the 'baptist-font cum alchemical vessel', and carried by a man on the ballustrade. Of interest is also the circumstance that the architectural structure over the niche behind the vessel is not yet completed, but is under construction. This may be an allusion to the rebuilding of Solomon's tempel, a prominent theme in later Hermeticism.

In sum, the texts and pictures are replete with a multivalence that enables the beholder, if he or she has knowledge of the subject, to explore the

\footnotetext{
${ }^{32}$ For an excellent religio-historic analysis of the motif of the baptism in fire and water generally, and also concerning Neoplatonic theurgy, see Edsman 1940: 174-180.
} 
intertextual web of the Hermetic discourse. But other decodings have also been tried.

\section{Psychoanalyzing the Hermetic Discourse}

In the foreword to his phenomenological study The Forge and the Crucible. The Origins and Structures of Alchemy, Mircea Eliade gives credit to Carl Gustav Jung and his analytic-psychological decoding of the alchemists quest for the Philosopher's Stone and the Elixir Vitae. ${ }^{33} \mathrm{Jung}$, according to Eliade, substantiates the soteriological purpose of alchemy, and has uncovered that the symbolism in the alchemical process is re-enacted in dreams and conversations of patients completely ignorant of alchemy (Eliade 1978: 11). Eliade, in this context, obviously accepts the claims of Jung concerning a collective unconscious and the existence of archetypes.

Jung's studies and theories of alchemy, which took up the last thirty years of his life and resulted in three substantial volumes in the collected works, are difficult both to describe and to evaluate. In them are mingled case-studies of patients whose dreams Jung has amplified ${ }^{34}-$ i.e. compared with recurrent alchemical themes - studies of specific texts, and their religio-historic implications, philosophical discussions, etc., Jung has, with a term taken from sixteenth century Hermetic literature, described the alchemists' quest as a circumambulatio - a wandering around certain themes that may lead to successive illumination - and he also uses this metaphor to describe how a patient works with the different subjects of his or her dreams (Jung 1968: 28).

In an article written for the Hebrew edition of the Encyclopedia Hebraica Jung has tried to recapitulate his thoughts, and takes his point of departure from the fact that even though the Late Antique alchemists had a considerable practical knowledge of the use of various substances, whether minerals or drugs, they had no real knowledge of chemistry proper. Instead, according to Jung, they used mythological motifs to 'explain' the un-

\footnotetext{
${ }^{33}$ Wikström, in the otherwise interesting article $C G$ Jung som teolog, has written rather abstrusely about Jung's view of alchemy, especially Metallen hade kropp och själ och metallens själ kunde nås genom en tillsats. Att framställa denna tillsats skulle leda till fyndet av 'De Vises sten' etc. A complicated Aristotelic and hylozoistic view of the elements cannot be described in such a simplistic way, and what does Wikström denote by tillsats - added ingredient? Wikström 1992: 56.

${ }^{34}$ The analytic-psychological correspondence to Eliadean phenomenology and its search for analogous patterns.
} 
known chemical processes, and they also projected their unconscious contents onto these processes, and thereby constructed an alchemical philosophy which mirrored both their unconscious and their conscious worldviews. This would explain an interesting feature of these texts; that on the one hand they repeat the sayings of the Ancients, and on the other allow free-flowing subjective fantasy. Jung is of the opinion that alchemical symbols are created both from traditions in a given culture, and from the unconscious (Jung 1986: 751-753).

In his studies Jung draws a parallel between the stages in the alchemical process and the stages in psychological maturing that he claims to take place in the process of individuation. ${ }^{35} \mathrm{He}$ compares the chaotic stage $\mathrm{Ni}$ gredo with the struggle of the individual to make conscious his shadow, those parts of his personality that he cannot consciously acknowledge and therefore projects onto others. An example is a timid individual who always thinks that all others are constantly angry, because he projects his own aggresions onto others, thereby not making conscious and using his own aggressions in a constructive way.

The Opus Alchemicum shows for Jung the individuation of man, and in his work Mysterium coniunctionis. Untersuchung über die Trennung und Zusammensetzung der seelischen Gegensätze der Alchemie claims that the famous alchemical wedding (Coniunctio Solis et Lunae) symbolizes the highest stage in the process of individuation; Selbstwerdung, to unite unconscious and conscious in a new center in the individual, which is not the Ego. This new center of consciousness, called the Self, is characterized, according to Jung, by the coincidence of opposites; conscious and unconscious, man and woman, spirit and body, good and evil, etc., and in their complete uniting in this higher synthesis. This correponds even to a loftier metaphysical entity the archetype of the self which for Jung seems to be a way of expressing the God of Nichts - the paradoxical God of the mystics (Jung 1950).

We can compare this with the outcome of the alchemical wedding in Splendor Solis, see illustr. 8 (fol. 32). A hermaphrodite, a complete man, a rebis to use the alchemical terminology, is set in beautiful natural scenery. It has a black robe and a white and red wing, alluding to the color-stages, and carries a round mirror and an egg. The mirror, which reflects the surroundings, is perhaps a visual hint of the common micro-macro correspondence with which the Hermetic literature is replete. The egg and its parts,

\footnotetext{
${ }^{35}$ This term is influenced from the principium individuationis of scholastic philosophy, the principle of what constitutes and distinguishes one individual from another.
} 
in the accompanying text, is likened to the four elements (shell = earth, the white $=$ water, the membrane between shell and the white $=$ air, the yolk = fire) and in the center of the yolk the fifth element, the quintessense, which has creative powers. Thus an egg contains all the forces together with the material out of which perfect nature is created. And it must also be so in this noble Art (Godwin's translation in Trismosin 1981:26).

\section{Eco's Thinking About Hermetic Semiosis and the Psy- cho-Analytical Decodings}

Eco, as has been stated in the introduction, presents a sketch of the semiotic workings of second century Hermetism, which emphasizes the similarities he sees between this literature and some more extreme readeroriented perspectives. A key to Eco's interpretation is the vital importance that he acknowledges micro- and macro-correspondences and the universal sympathy, as here below so in heaven above, as constituting the worldview of Hermetism. He writes:

It is only possible to speak of universal sympathy and likeness if, at the same time, the principle of non-contradiction is rejected. Universal sympathy is brought about by a godly emanation in the world, but at the origin of the emanation there is an unknowable One, who is the very seat of the contradiction itself. Neo-platonist Christian thought will try to explain that we cannot define God in clear-cut terms on account of the inadequacy of our language. Hermetic thought states that our language, the more ambiguous and multivalent it is, and the more it uses symbols and metaphors, the more it is particularly appropriate for naming a Oneness in which the coincidence of opposites occurs. But where the coincidence of opposites triumphs, the principle of identity collapses. Tout se tient. (Eco 1992: 32)

Eco, accordingly, interprets Hermetism as a negation of the classical Greek rationalism of Plato and Aristotle, in which knowledge meant understanding causes and the acceptance of the logical principles of identity $(A=A)$, non-contradiction and the excluded middle. In a worldview, the Hermetic for instance, characterized by sympathetic thinking, where a part of the human body is linked, on the basis of partial morphological and functional likeness to a plant, and that plant is said to resemble a star-constellation, etc., a continuous slippage of meaning occurs. ${ }^{36}$ Every object in the universe refers to other objects in a secret way, writes Eco, in a progressive evolu-

\footnotetext{
${ }^{36}$ For the physiognomic tradition, that manifest signs in the appearance of man or animal act as indices for their inner traits and constitution, see Broek 1987: 111-116).
} 
tion toward a final secret. This can perhaps be called an infinitive regression of meaning, and it is Eco's opinion that this way of thinking transforms the view of the world into a linguistic phenomenon and at the same time denies language any power of communication (Eco 1992: 32).

It also seems that many things can be true at the same time, even if they contradict each other. The Hermetist has the attitude, according to Eco, that if the tractates tell the truth, even when they utter different opinions on a particular problem, then their each and every word must be an allegory, an allusion. Truth is revealed by vision, dream and oracle and is identified with what is not said or what is said obscurely to be read beyond or beneath an explicit meaning (Eco 1992: 30-32).

A Hermetic approach to texts, including modern deconstructivist and reader-oriented Hermetica is, according to Eco, characterized by an insistence that a text is an open-ended universe in which the reader can find infinite interconnections. Language shows, in this Hermetic view, that our thinking with its constant search for transcendental meaning is a failure, and that language itself cannot grasp a unique and pre-existing meaning. Eco writes with exuberant irony:

To salvage the text - that is, to transform it from an illusion of meaning to the awareness that meaning is infinitive - the reader must suspect that every line of it conceals another secret meaning; words, instead of saying, hide the untold; the glory of the reader is to discover that texts can say everything, except what their author wanted them to mean; as soon as a pretended meaning is discovered, we are sure that it is not the real one; the real one is the further one and so on and so forth; the hulics - the losers - are those who end the process by saying 'I understood'. (Eco 1992: 39)

Jung can be said - I want to argue, using Eco's way of analysis - to continue the Hermetic project by his constant use of Hermetic semiosis, that the intentions of the reader have triumphed, and, paradoxically, in the case of Jung, a reader with Hermetic leanings, resulted in that his analysis, including the process of individuation, is not a psychological analysis but an analogy to the Hermetic literature. It can be seen as a very erudite paraphrasis, in which the soteriological tendencies of alchemy have been internalized in a supposed mental topography - the unconscious enveloped by the collective unconscious with its archetypes - which, paradoxically, is a continuation of well-known themes from Late Antique Neoplatonism, Hermetism, and Gnosticism: The katabasis from Pleroma of emanations (the individual struggling to find his own individuality) resulting in a fallen Creation with Man struggling to regain knowledge (consciousness) by liberation from the grip of fallen material nature. The regaining of knowledge 
by undressing the material body and its sensations in an anabasis back to the restituted Completeness (Selbstwerdung).

I want to argue that Jung ought to be seen in the context of the esoteric parts of German romanticism, with its roots in Neoplatonism, and in Paracelsism, Hermetic Naturphilosophie, Rosicrucianism and Freemasonry, and in the mystical theologies of Nicholaus Cusanus and Jakob Böhme. His interpretation of alchemy is congenial with the semiotic workings of the subject and it creates a world in which everything 'fits' according to a reader with a Jungian intention. The reader's intention is victorious over the intention of the text. Perhaps it can be said that Jung's alchemical studies are more an object of study for the historian of religions than an instrument that could be put to use in our academic discourse.

Furthermore, I think it would be wise to consider the chemical and/or the religious- soteriological decodings as primary and nearly always present in the hermetic-alchemical material. The psychoanalytical decoding is of a secondary nature and it is always juxtaposed to a religious-soteriological decoding. But these circumstances do not altogether diminish the fact that we can in Jung's work find very penetrating observations of the workings of Hermetic literature and of the psychological predicament of Mankind.

\section{Eco's Model of the Intentions of the Texts, Readers and Authors Used on the Hermetic Discourse}

As a summary of what has been discussed, especially concerning the three main decodings of alchemy, I will use the following model of the intentions of the texts, readers and authors, proposed by Eco (1992: 45-66), which I have tried to graphically depict (see Fig. 1.)

The purpose of the model is to elucidate the relations between the intentions of readers, texts, and authors. What is then a text, and what is the intention of a text? The text, Splendor Solis (or Zosimos' Of Virtue, and of course, in extension, the whole of the Hermetic literature and other texts), is a device conceived in order to produce its model reader. ${ }^{37}$ The decisive choice is then the type of model reader that is chosen, because, according to Eco, the empirical reader is only an actor who makes conjectures about the kind of model reader postulated by the text. Is it the text's intention to produce a chemical, a spiritual or a psychological model reader?

\footnotetext{
${ }^{37}$ This and the following italicized citations are from Eco 1992: 64-66.
} 
Figure 1. Eco's Model of the Intentions of Texts, Readers, and Authors

Depicted graphically by Peter Södergàrd, and with relevant information concerning Salomon Trismosin's Splendor Solis incerted. All the citations from Eco are italicized.

(Intrinsic Factors of Texts)

The Text

Splendor Solis

A text is a devise conceived in order to produce its Model reader.

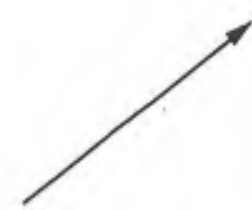

Model Author

Salomon Trismosin,

whose intentions can only

be established by reading

the text.

To prove a conjecture about the intentio operis: check it upon the text as a coherent whole
Model Reader

The initiative of the model reader consists in figuring out a model author that is not the empirical one and that, in the end, coincides with the intention of the text .

\begin{tabular}{|l|l|}
\hline $\begin{array}{l}\text { Empirical Author } \\
\text { A unknown redactor that } \\
\text { has put together Splendor Solis } \\
\text { out of the sayings of the Ancients }\end{array}$ & $\begin{array}{l}\text { Empirical Reader } \\
\text { The empirical reader is only } \\
\text { an actor who makes } \\
\text { conjectures about the kind of } \\
\text { model reader postulated by the } \\
\text { text. }\end{array}$ \\
\hline
\end{tabular}


The person who answers this intriguing question is the empirical reader, he or she is only an actor who makes conjectures about the kind of model reader postulated by the text.

In this article we have been confronted with some empirical readers which make conjectures about the dissimilar model readers that they propose the text is producing. Subsequently, we have a set of proposed model readers with different intentions; a chemical, spiritual, and psychological. These model reader seem almost to have come to life, due to the seduction of the illusive world of the narrative, and they declare unanimously that the model author's name is Salomon Trismosin. They have all figured out that the model author, Salomon Trismosin, is not the empirical writer of the text. But instead they have found out that the intention of the model author Salomon Trismosin, in the end, coincides with the intention of the text.

To prove a conjecture about the intention of the text, which is done by empirical readers, Eco prescribes a remedy that is common in hermeneutics, but he also gives it a Freudian flavor; check it upon the text as a coherent whole. The internal textual coherence controls the uncontrollable drives of the reader.

It is at this point that the special feature of the Hermetic discourse comes into focus: Hermetic semiosis, which I propose can be held responsible for the divergent readings that have been proposed, a continuum from a chemical reading to a soteriological, and with a psychological reading which has been built upon the latter. ${ }^{38}$ The intention of the text, whether Splen-

\footnotetext{
${ }^{38}$ This also holds for the Freudian reading proposed by Herbert Silberer, which interpret alchemy and its symbols as symptoms of the Oedipal-complex, erupting with regressive sexuality (Silberer 1914: 33-114). This decoding, and the reading of a taoist alchemical tractate translated by the Sinolog Richard Wilhelm inspired C. G. Jung's interpretation according to Jung's own autobiography (Jung 1979: 230). Another psychological interpretation was proposed by the Dane Johannes Fabricius in an exquisitely illustrated volume. Fabricius, when describing the individuation process on the basis of the woodcuts in the Rosarium philosophorum (in Artis auriferae, Basel 1610), even surpasses Jung's own imagination, and writes: After penetrating the reflecting and autistic surface of his queen's well, the king changes from Narcissus into King Oedipus, gradually activating the birth trauma as he attempts to penetrate the royal well and its vaginal libido organization. At the bottom of the well the king reaches the mercurial ocean and its uterine libido organization, thereby fusing into hermaphroditic unity with his queen in the water of life (Fabricius 1976: 226). The psychological interpretation functions here as a totalizing discourse which sees psychological processes in
} 
dor Solis, or Zosimos' Of Virtue, is not univocal, but decidedly equivocal. It appears to be contrived with a built in ambiguity due to the Hermetic world view. This world view, dominated by correspondences, creates, as Eco has stated, a universe replete with infinitive signs pointing to other signs in a continuous slippage of meaning. The final sign is always just another sign pointing to a sign.

To sum up my views: I - the narrator in the text of this article in the Scripta Instituti Donneriani - I am only an actor making hypotheses about the model reader I conjecture Splendor Solis is producing. My hypothesis is that the name of the model author, Salomon Trismosin, functions as an indication that the tractate is creating a model reader, who is reading the Hermetic discourse as intending both a chemical, and a soteriological reading. It is possible to misread with Jung, and to conjecture that the text of Splendor Solis is producing a reader intending on the individuation-process, but this is an overinterpretation which the text as a coherent whole repudiates.

The chemical and religious-soteriological interpretations are primary and encoded in the text. The intentio operis consists of them. Jung's decoding of the alchemical transmutation process with its three or four stages as a homologization - reflection - of the process of individuation is building upon the religious-soteriological interpretation and is therefore of a secondary nature. It can be considered as a congenial paraphrase of Hermetic theology using concepts emanating from the same tradition.

I - the narrator who is addressing you, the narratee, in this article hereby performatively end it with the intention that you will be its model reader, who figures out a model author writing about the semiosis of the Hermetic discourse.

\section{References Cited}

Albinus, Lars

1994 Diskurs-begrebet i religionshistorisk kontekst. En nøgle til forståelse af religiøse transformationsprocesser i antikken. Religionsuidenskabelig Tidsskrift 24: 13-38.

Bagnall, Roger S.

1993 Egypt in Late Antiquity. Princeton: Princeton University Press.

Berthelot, $M$.

1888 Collection des anciens alchimistes grecs. 3 vols. Paris: G. Steinheil.

each and every thing, taking leave of any regard for the alchemical text as a coherent whole, and instead offers a psychologizing reduction. 


\section{Birkhan, Helmuth}

1992 Die alchemistische Lehrdichtung des Gratheus filius philosophi in Cod. Vind. 2372. Zugleich ein Beitrag zur okkulten Wissenschaft im Spätmittelalter; vol. 1. Wien: Verlag der Österreichischen Akademie der Wissenschaften. Wien: Verlag der Österreichische Akademie der Wissenschaften. (Sitzungsberichte. Österreichische Akademie der Wissenschaften. Phil.Hist. Klasse, 591)

Broek, Gerard J. van den

1987 Signs and Signatures: Reading God's Herbal. Semeiotica 63: 109-128.

Cameron, Averil

1991 Christianity and the Rhetoric of Empire. The Development of Christian Discourse. Berkeley: University of California Press. (Sather Classical Lectures, 55)

Christie, Agatha

1977 The Thirteen Problems. London: Pan Books. [1932]

Craddock, Paul T., and Alessandra R. Giumlia-Mair

1993 Corinthium aes. Das schwarze Gold der Alchimisten. Antike Welt. Zeitschrift für Archäologie und Kulturgeschichte 24: 2-62.

Eco, Umberto

1992 Interpretation and Overinterpretation. Ed. by Stefan Collini. Cambridge: Cambridge University Press.

Edsman, Carl-Martin

1940 Le baptême du feu. Uppsala: Lundequistska bokh. (Acta Seminarii Neotestamentici Upsaliensis, 9)

Eliade, Mircea

1978 The Forge and the Crucible. Chicago: University of Chicago Press. [2d ed.]

Fabricius, Johannes

1976 Alchemy. The Medieval Alchemists and their Royal Art. Copenhagen: Roskilde and Bagger.

Ferguson, John

1906 Bibliotheca Chemica. A Catalogue of the Alchemical, Chemical and Pharmaceutical Books in the Collection of the late James Young of Kelly and Durris...; vol. 1. Glasgow: James Maclehose and Sons.

Festugière, R. P.

1950 La Révélation D'Hermès Trismégiste; vol. 1: L'Astrologie et les Sciences Occultes. Paris: Libraire Lecoffre.

Foucault, Michel

1979 What is an Author? In: Josué V. Harari (ed.), Textual Strategies. Perspectives in Post-structuralist Criticism; pp. 141-160. London: Methuen.

Fowden, Garth

1993 The Egyptian Hermes. A Historical Approach to the Late Pagan Mind. Princeton: Princeton University Press. [1986]

Gundel, $w$

1950 Alchemie. In: Theodor Klauser (ed.), Reallexikon für Antike und Christentum, vol. 1; pp. 239-260. Stuttgart: Hiersemann. 


\section{Halleux, Robert}

1979 Les textes alchimiques. Turnhout: Brepols. (Typologie des sources du Moyen Âge occidental, 32)

Halleux, Robert (ed.)

1981 Les Alchimistes grecs; vol. 1. Paris: Belles Lettres.

Hartlaub, Gustav Friedrich

1991 Kunst und Magie. Gesammelte Aufsätze. Ed. by Norbert Miller, pp. 126-143. Hamburg: Luchterhand Literaturverlag. (Veröffentlichungen der Deutschen Akademie für Sprache und Dichtung Darmstadt, 65).

\section{Holmyard, Eric John}

1957 Alchemy. Middlesex: Penguin Books.

Hopkins, A. J.

1938 A study of the Kerotakis process as given by Zosimus and later alchemical writers. Isis $29: 326-354$.

Jung, C. G.

1950 Mysterium Coniunctionis: Untersuchung über die Trennung und Zusammensetzung der seelischen Gegensätze in der Alchemie; vol. 1. Zürich: Rascher Verlag. (Psychologische Abhandlungen, 9)

1968 Psychology and Alchemy. [2nd ed. completely rev.] Princeton: Princeton University Press. (Collected Works, 12)

1979 Memories, Dreams, Reflections. Ed. by Aniela Jaffé. Glasgow: Collins Fount Paperbacks.

1986 The Symbolic Life. Miscellaneous Writings. Princeton: Princeton University Press. (Collected Works of C. G. Jung, 18) (Bollingen series, 20) $[1976]$

[K] ohn, [J] ulius

1920 Splendor Solis. Alchemical Treatises of Solomon Trismosin, Adept and Teacher of Paracelsus. Including 22 Allegorical Pictures from the Original Paintings dated 1582, in the British Museum... and Explanatory Notes by J. K. London: Kegan Paul.

\section{Kopp, Hermann}

1886 Die Alchemie in älterer und neuerer Zeit. Ein Beitrag zur Culturgeschichte; vol. 1. Heidelberg: Carl Winter's Universitätsbuchhandlung.

Lennep, Jacques van

1984 Alchimie. Contribution à l'histoire de l'art alchimique. Bruxelles: Crédit communal.

Linds ay, Jack

1970 The Origins of Alchemy in Graeco-Roman Egypt. London: Frederick Muller.

Lippmann, Edmund O. von

1919 Entstehung und Ausbreitung der Alchemie. Berlin: Julius Springer.

Needham, Joseph

1974 Science and Civilization in China; vol. 5: Chemistry and Chemical Technology; pt 2: Spagyrical Discovery and Invention: Magisteries of Gold and Immortality. Cambridge: Cambridge U. P. 


\section{Nilsson, Martin P.}

1958 Krater. Harvard Theological Review 51: 53-58.

Patai, Raphael

1994 The Jewish Alchemists. A History and Source Book. Princeton: Princeton University Press.

\section{Sezgin, Fuat}

1971 Geschichte des arabischen Schrifttums; vol. 4: Alchimie, Chemie, Botanik, Agrikultur bis ca. $430 \mathrm{H}$. Leiden: E. J. Brill.

\section{Sheppard, Harry J.}

1986 European Alchemy in the Context of a Universal Definition. In: Christoph Meinel (ed.), Die Alchemie in der europäischen Kultur- und Wissenschaftsgeschichte; pp. 13-17. Wiesbaden: In Kommission bei Otto Harrassowitz. (Wolfenbütteler Forschungen, 32).

\section{Silberer, Herbert}

1914 Probleme der Mystik und ihrer Symbolik. Wien.

Taylor, F. Sherwood

1930 A Survey of Greek Alchemy. The Journal of Hellenic Studies 50: 109139.

1937 The Visions of Zosimos. Ambix 1: 88-92.

Trismosin, Salomon

1981 Splendor Solis. Introd. by Adam McLean. Edinburgh: Magnum Opus Hermetic Sourceworks. (Magnum Opus Hermetic Sourceworks, 8)

\section{Warwick Montgomery, John}

1963 Cross, Constellation, and Crucible: Lutheran Astrology and Alchemy in the Age of the Reformation. Ambix 11: 65-86.

Wikström, Owe

1992 C. G. Jung som teolog. Signum. Katolsk orientering om kyrka, kultur, samhälle 18: 52-57.

\section{Zosime de Panopolis}

1995 Les Alchimistes grecs. Ed. by Robert Halleux; t. 4, pt. 1: Zosime de Panopolis, Memoires authentiques. Ed. by Michèle Mertens. Paris: Belles Lettres. 